\title{
Energy and protein levels in diets containing phytase for broilers from 22 to 42 days of age: performance and nutrient excretion ${ }^{1}$
}

\author{
Adriano Kaneo Nagata ${ }^{2}$, Paulo Borges Rodrigues ${ }^{3}$, Renata Ribeiro Alvarenga ${ }^{3}$, Márcio \\ Gilberto Zangeronimo ${ }^{4}$, Kênia Ferreira Rodrigues ${ }^{5}$, Gustavo Freire Resende Lima ${ }^{6}$
}

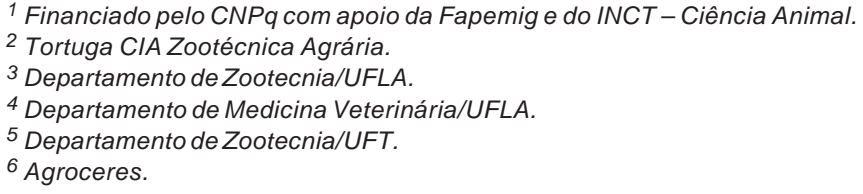

ABSTRACT - This study was conducted in order to evaluate the influence of different levels of metabolizable energy and crude protein in diets formulated according to the ideal protein concept with phytase supplementation on performance and nutrient excretion of broilers from 22 to 42 days age. It was used 1,500 Coob lineage broilers at 22 days of age and with initial weight of $833 \pm 7 \mathrm{~g}$, distributed in completely randomized design in a $3 \times 3+1$ factorial scheme composed of three levels of correct apparent metabolizable energy $(2,950 ; 3,100$ and 3,250 kcal/kg), three levels of crude protein (14, 16 and $18 \%)$ and a control treatment, totaling ten treatments with six repetitions of 25 birds each. All diets, with the exception of the control, were supplemented with phytase. For determination of excretion of pollutants, it was used 180 broilers from the same lineage at 35 days of age,placed in metabolic cages, with ten treatments each one with six repetitions and three birds per experimental unit. The protein and energy levels in diets containing phytase influenced feed intake, weight gain, feed conversion and excretion of nitrogen, phosphorus, calcium, potassium, copper and zinc by the birds. The corrected apparent metabolizable energy level in the diets for broilers in the studied period must be increased up to $3,250 \mathrm{kcal} / \mathrm{kg}$ of metabolizable energy and the levels of crude protein, calcium and phosphorus must be reduced down to $18,0.70$ and $0.31 \%$, respectively, provided that supplemented with amino acids and phytase to improve the performance and to reduce excretion of pollutants by birds.

Key Words: addictive, available phosphorus, enzyme, ideal protein, metabolizable energy, pollutants

\section{Introduction}

Balancing diets to improve the performance and to reduce the environmental impact caused by poultry waste has been the subject of research in recent years, isnasmuch as current systems of poultry farming are basically in total confinement and at high densities. This fact has generated considerable amount of waste which can contaminate the environment as a result of high levels of nitrogen and some minerals in the feces of birds.

Thus, the formulation of diets based on ideal protein and digestible amino acids have been widely considered by nutritionists. The provisions of balanced diets improve the efficiency of nutrient use by animals and reduce the environmental impact caused mainly by nitrogen and phosphorus.

According to Gates (2000), low crude protein diets containing essential amino acids reduce the nitrogen concentration in waste. In addition, the use of additives that increase the digestibility of nutrients is also considered as a way to reduce environmental impact.

The addition of phytase in poultry diets has been effective in improving the use of organic phosphorus and, at the same time, reducing the excretion of this element. Furthermore, it has been postulated some positive effects on the metabolizable energy of the diets and digestibility of the nutrients such as protein, amino acids, zinc and copper. Camden et al. (2001) observed that the addition of phytase in low available phosphorus and calcium diets for broilers in the initial phase improved nitrogen and phosphorus retention, reducing the amount of these elements in the excrements. This suggests an interaction of phytase with the other ingredients, which would permit a reduction in crude protein and an increase in the metabolizable energy of diets.

This study was conducted to evaluate the metabolizable energy levels in low-crude protein, phosphorus and calcium diets, supplemented with crystalline amino acids and phytase for broilers from 22 to 42 days of age. 


\section{Material and Methods}

The experiment was conducted at the Setor de Avicultura in the Departamento de Zootecnia of Universidade Federal de Lavras (UFLA) in Lavras, Minas Gerais, Brazil.

One thousand and five hundred male Cobb chicks at 22 days of age and initial weight of $833.0 \pm 7.0$ g were randomly distributed into 60 boxes with wood shavings covered floors, tubular feeder and bell drinkers. Water and food were supplied ad libitum. The experimental period was 20 days.

The completely randomized design in factorial $3 \times 3+1$ (three levels of apparent metabolizable energy $-2,950,3,100$ and 3,250 kcal/kg - and three of crude protein - 14, 16 and
$18 \%$ - and a control diet) totalizing ten treatments with six replicates of 25 birds each was used. Control diet was formulated according to Rostagno et al. (2000).

The diets were based on corn and soybean meal, mantaining amino acids:lysine ratio, according to the ideal protein concept (Table 1). Except for the control diet, all experimental diets had 500 FTU of phytase $/ \mathrm{kg}$ (Ronozyme - $5000 \mathrm{PTU} / \mathrm{g}$ ), available phosphorus reduced from 0.40 to $0.31 \%$ and calcium from 0.89 to $0.71 \%$.

Animals were weighted at the beginning and at the end of the experimental period to calculate the weight gain. Feed intake was estimated by the difference between feed and leftovers. The feed:gain ratio was the relationship between feed intake and weight gain of birds in each experimental unit.

Table 1 - Percentage composition of experimental diets

\begin{tabular}{|c|c|c|c|c|c|c|c|c|c|c|}
\hline \multirow[t]{2}{*}{ Ingredients } & \multirow[t]{2}{*}{ Control diet } & \multicolumn{3}{|c|}{$14 \%$ CP } & \multicolumn{3}{|c|}{$16 \%$ CP } & \multicolumn{3}{|c|}{$18 \%$ CP } \\
\hline & & $2,950^{1}$ & 3,100 & 3,250 & 2,950 & 3,100 & 3,250 & 2,950 & 3,100 & 3,250 \\
\hline Corn & 61.700 & 73.100 & 73.100 & 73.100 & 68.800 & 68.800 & 68.800 & 63.300 & 63.300 & 63.300 \\
\hline Soybean meal & 30.530 & 16.900 & 16.900 & 16.900 & 22.200 & 22.200 & 22.200 & 27.620 & 27.620 & 27.620 \\
\hline Kaulin & 0.404 & 4.024 & 2.344 & 0.644 & 3.554 & 1.844 & 0.134 & 3.584 & 1.884 & 0.184 \\
\hline Dicalcium phosphate & 1.580 & 1.200 & 1.200 & 1.200 & 1.170 & 1.170 & 1.170 & 1.100 & 1.100 & 1.100 \\
\hline Soybean oil & 3.740 & 1.200 & 2.880 & 4.580 & 1.450 & 3.160 & 4.870 & 2.180 & 3.880 & 5.580 \\
\hline Limestone & 1.020 & 0.860 & 0.860 & 0.860 & 0.840 & 0.840 & 0.840 & 0.840 & 0.840 & 0.840 \\
\hline Salt & 0.480 & 0.480 & 0.480 & 0.480 & 0.480 & 0.480 & 0.480 & 0.480 & 0.480 & 0.480 \\
\hline L-lysine $\mathrm{HCl}$ 79\% & 0.180 & 0.610 & 0.610 & 0.610 & 0.450 & 0.450 & 0.450 & 0.300 & 0.300 & 0.300 \\
\hline DL-methionine 99\% & 0.200 & 0.330 & 0.330 & 0.330 & 0.280 & 0.280 & 0.280 & 0.240 & 0.240 & 0.240 \\
\hline L-valine & - & 0.280 & 0.280 & 0.280 & 0.200 & 0.200 & 0.200 & 0.110 & 0.110 & 0.110 \\
\hline L-arginine & - & 0.360 & 0.360 & 0.360 & 0.210 & 0.210 & 0.210 & 0.050 & 0.050 & 0.050 \\
\hline L-threonine & - & 0.130 & 0.130 & 0.130 & 0.070 & 0.070 & 0.070 & - & - & - \\
\hline L-isoleucine & - & 0.210 & 0.210 & 0.210 & 0.120 & 0.120 & 0.120 & 0.020 & 0.020 & 0.020 \\
\hline L-tryptophan & - & 0.050 & 0.050 & 0.050 & - & - & - & - & - & - \\
\hline L-phenylalanine & - & 0.090 & 0.090 & 0.090 & - & - & - & - & - & - \\
\hline Vitamin $\operatorname{mix}^{2}$ & 0.035 & 0.035 & 0.035 & 0.035 & 0.035 & 0.035 & 0.035 & 0.035 & 0.035 & 0.035 \\
\hline Mineral $\operatorname{mix}^{3}$ & 0.050 & 0.050 & 0.050 & 0.050 & 0.050 & 0.050 & 0.050 & 0.050 & 0.050 & 0.050 \\
\hline Colin chloride $60 \%$ & 0.050 & 0.050 & 0.050 & 0.050 & 0.050 & 0.050 & 0.050 & 0.050 & 0.050 & 0.050 \\
\hline Salinomicin 12 \% & 0.021 & 0.021 & 0.021 & 0.021 & 0.021 & 0.021 & 0.021 & 0.021 & 0.021 & 0.021 \\
\hline Zinc bacitracin & 0.010 & 0.010 & 0.010 & 0.010 & 0.010 & 0.010 & 0.010 & 0.010 & 0.010 & 0.010 \\
\hline Phytase $^{4}$ & - & 0.010 & 0.010 & 0.010 & 0.010 & 0.010 & 0.010 & 0.010 & 0.010 & 0.010 \\
\hline \multicolumn{11}{|l|}{ Calculated value } \\
\hline Crude protein (\%) & 19.20 & 14.00 & 14.00 & 14.00 & 16.00 & 16.00 & 16.00 & 18.00 & 18.00 & 18.00 \\
\hline AMEn (kcal/kg) & 3,100 & 2,950 & 3,100 & 3,250 & 2,950 & 3,100 & 3,250 & 2,950 & 3,100 & 3,250 \\
\hline Calcium (\%) & 0.90 & 0.70 & 0.70 & 0.70 & 0.70 & 0.70 & 0.70 & 0.70 & 0.70 & 0.70 \\
\hline Available phosphorus (\%) & 0.40 & 0.31 & 0.31 & 0.31 & 0.31 & 0.31 & 0.31 & 0.31 & 0.31 & 0.31 \\
\hline Digestible lysine (\%) & 1.04 & 1.05 & 1.05 & 1.05 & 1.05 & 1.05 & 1.05 & 1.06 & 1.06 & 1.06 \\
\hline Methionine + cystine (\%) & 0.74 & 0.75 & 0.75 & 0.75 & 0.75 & 0.75 & 0.75 & 0.75 & 0.75 & 0.75 \\
\hline Digestible threonine (\%) & 0.65 & 0.59 & 0.59 & 0.59 & 0.61 & 0.61 & 0.61 & 0.61 & 0.61 & 0.61 \\
\hline Digestible tryptophan (\%) & 0.21 & 0.19 & 0.19 & 0.19 & 0.17 & 0.17 & 0.17 & 0.20 & 0.20 & 0.20 \\
\hline Digestible isoleucine (\%) & 0.74 & 0.72 & 0.72 & 0.72 & 0.72 & 0.72 & 0.72 & 0.71 & 0.71 & 0.71 \\
\hline Digestible arginine (\%) & 1.18 & 1.15 & 1.15 & 1.15 & 1.16 & 1.16 & 1.16 & 1.15 & 1.15 & 1.15 \\
\hline Digestible valine (\%) & 0.79 & 0.85 & 0.85 & 0.85 & 0.86 & 0.86 & 0.86 & 0.85 & 0.85 & 0.85 \\
\hline Digestible phenylalanine (\%) & 0.87 & 0.71 & 0.71 & 0.71 & 0.72 & 0.72 & 0.72 & 0.81 & 0.81 & 0.81 \\
\hline
\end{tabular}


In addition to the performance experiment, a metabolism trial was conducted with 180 Cobb broilers at 35 days of age, which were randomly distributed into cages $(50 \times 50 \times 50 \mathrm{~cm})$ containing drip watering place and feeders and excreta collection pans. The birds were housed in an environment controlled by automatic fans turned on/off by a thermostat. Artificial light was provided for 24 hours. Water and food were supplied ad libitum. The experimental period was seven days.

The traditional method of total excreta collection (Matterson et al., 1965) was used. Initially, feed samples were taken for laboratory analysis. Birds were adapted to cages and diets during four days. Three days were used to total excreta collection (Robinson et al., 2005). Excrements were collected in plastic-covered trays without feathers. Food scrap and excrements were frozen until the end of the experimental period. Samples were then collected for chemical analysis described by Silva (2002).

Gross energy, nitrogen, phosphorus, calcium, potassium, zinc and copper concentration were determined in the diets and excrements. In order to calculate the AMEn (nitrogen-corrected apparent metabolizable energy) of the diets, the equations described by Matterson et al. (1965) were used. The coefficients of apparent retention of nitrogen, phosphorus, calcium, potassium, zinc and copper were calculated using the following formula:

Coefficient of retention $(\%)=$ ingested nutrient $(\mathrm{g})-$ excreted nutrient $(\mathrm{g}) \quad \times 100$ ingested nutrient $(\mathrm{g})$

Weight gain, feed intake, feed:gain ratio, apparent metabolizable energy, nitrogen-corrected apparent metabolizable energy and consumption, excretion and coefficient of retention of nitrogen, phosphorus, calcium, potassium, copper and zinc were evaluated. Data were submitted to analysis of variance. Firstly, a global analysis was made considering all treatments to obtain the mean square residue which was used to test the factorial and to conduct the Dunnett test at 5\% comparing the control diet to the others. The factorial treatments were evaluated by Student-Newman-Keuls (SNK) test at 5\%. All statistical analysis were performed by using the statistical program SISVAR described by Ferreira (2000).

\section{Results and Discussion}

The inclusion of phytase reduced the energy levels down to 3,100 kcal AMEn/kg and the crude protein to $16 \%$ in diets supplemented with amino acids, maintaining the performance of broilers from 22 to 42 days of age (Table 2). However, lower feed intake $(\mathrm{P}<0.05)$ without affecting the weight gain $(\mathrm{P}>0.05)$ of the birds was obtained with $3,250 \mathrm{kcal}$ AMEn/ $\mathrm{kg}$ and $18 \%$ of crude protein in the diets.

These results are consistent with Rostagno et al. (2002) who reported that dietary protein may be reduced down to $16 \%$ by using crystalline amino acids and correcting the electrolyte balance. However, these authors worked with normal levels of phosphorus, without enzymes in the diets. Fernandes et al. (2005), using sorghum and soybean mealdiets, reported that protein can be reduced only by one percentage point in all stages of rearing without affecting the broiler performance provided that methionine, lysine, threonine and tryptophan are maintained in the diets. Similar results were obtained by Rigueira et al. (2005), who, by applying the ideal protein concept, concluded that $18 \%$ of crude protein is needed to ensure the maximum performance of broilers from 21 to 35 days of age. Barbosa et al. (2005) reported that $17 \%$ of crude protein can maintain the performance of broilers from 22 to 42 days of age. These results may be caused by genetic variability of animals, the experimental conditions and the amount of feed and amino acids in the diets.

Similar results were obtained by Gomide et al. (2007), when evaluating nutritional plans for broilers. These authors also reported no adverse effects with diets containing $16 \%$

Table 2 - Performance of broilers from 22 to 42 days of age fed diets containing different levels of energy and protein supplemented with fitase ${ }^{1}$

\begin{tabular}{|c|c|c|c|c|}
\hline \multirow[t]{2}{*}{ AMEn level (kcal/kg) } & \multicolumn{3}{|c|}{ Crude protein (\%) } & \multirow[t]{2}{*}{ Mean } \\
\hline & 14.0 & 16.0 & 18.0 & \\
\hline & \multicolumn{3}{|c|}{ Feed intake (g) } & \\
\hline 2,950 & 3,586 & 3,599 & 3,534 & $3,573 \mathrm{~A}$ \\
\hline 3,100 & 3,509 & 3,516 & 3,503 & $3,509 \mathrm{~B}$ \\
\hline 3,250 & 3,429 & 3,396 & $3,340 *$ & $3,388 \mathrm{C}$ \\
\hline Mean & 3,508 & 3,504 & 3,459 & 3,490 \\
\hline Control $^{2}$ & 3,487 & & & \\
\hline \multirow[t]{2}{*}{ Coefficient of variation (\%) } & 2.50 & & & \\
\hline & \multicolumn{3}{|c|}{ Weight gain (g) } & \\
\hline 2,950 & $1,808^{*}$ & 1,923 & 1,887 & 1,873 \\
\hline 3,100 & $1,862 *$ & 1,923 & 1,972 & 1,919 \\
\hline 3,250 & 1,899 & 1,906 & 1,933 & 1,913 \\
\hline Mean & $1,856 b$ & $1,917 \mathrm{a}$ & $1,931 \mathrm{a}$ & 1,901 \\
\hline Control & 1,967 & & & \\
\hline
\end{tabular}

Coefficient of variation (\%) 3.04

$\begin{array}{lllll}\text { 2,950 } & 1.98^{*} & 1.87 * & 1.87 * & 1.91 \mathrm{~A} \\ 3,100 & 1.88^{*} & 1.83 & 1.78 & 1.83 \mathrm{~B} \\ 3,250 & 1.81 & 1.78 & 1.73 & 1.77 \mathrm{C} \\ \text { Mean } & 1.89 \mathrm{a} & 1.83 \mathrm{~b} & 1.79 \mathrm{c} & 1.84 \\ \text { Control } & 1.77 & & & \\ \text { Coefficient of variation (\%) } & 2.33 & & & \\ \text { * } \text { Differ from control diet by Dunnet test (P<0.05). } & & \\ { }^{1} \text { Means followed by different lowercase letters within line and capital letters } \\ \text { within column differ by SNK test (P<0.05). } \\ { }^{2} \text { Control diet containing 19\% of crude protein and 3,100 kcal/kg of metabolizable } \\ \text { energy. }\end{array}$

R. Bras. Zootec., v.40, n.8, p.1718-1724, 2011 
of crude protein and phytase. In this case, the available phosphorus was reduced to $0.31 \%$ showing that this enzyme was efficient in releasing this element for animal metabolism.

Considering only diets containing phytase, there was no interaction $(\mathrm{P}>0.05)$ between energy and protein levels considering the performance of the birds. The lower values of feed intake and feed:gain was obtained with $3,250 \mathrm{kcal}$ of AMEn $/ \mathrm{kg}(\mathrm{P}<0.05)$ whereas diets containing $18 \%$ of crude protein increased the weight gain and decreased the feed:gain $(\mathrm{P}<0.05)$. These results are consistent with those found by Silva et al. (2001), working under the same conditions with broilers from 22 to 42 days of age. These authors observed that increasing the metabolizable energy in diets without phytase decreased the feed:gain.

Studying the physiological behavior of animals under heat stress, Oliveira et al. (2000) also observed similar results of the energy levels of diets on performance of the birds fed diets without phytase. In this case, the higher weight gain resulted in lower feed:gain. On the other hand, Barbosa et al. (2008) also working under high temperature levels, observed an effect on feed intake only from 22 to 42 days of age. These differences considering the effects of energy levels may be due to different strains and experimental conditions. Results obtained in the present work suggest that the levels of metabolizable energy in diets with or without phytase for broilers have the same influence on performance.

The results obtained with the protein levels were similar to those found by Faria Filho et al. (2005) and Vieira et al. (2007). These authors worked with chickens on the initial and growth phase fed diets with or without phytase, respectively, and observed an increase of feed:gain with reduced crude protein diet. Silva et al. (2006) observed higher weight gain and lower feed intake when increasing crude protein from 15 to $19 \%$ in diets for broilers in initial phase with or without phytase. According to Oliveira Neto \& Oliveira (2009), studies should also be conducted to determine the requirements of non-essential amino acids which become limiting when the crude protein is reduced in broiler diets. This is due to the difference in the rate of absorption of these nutrients in synthetic or natural form, which could cause an imbalance in the cellular sites of protein synthesis. This would explain the lower weight gain and worse feed:gain ratio observed in broilers fed diets containing higher amount of crystalline amino acids than controls. This theory may be even more evident in diets containing phytase inasmuch as there are works reporting that this enzyme may provide more dietary amino acids for animals. Thus, further studies should be conducted to verify the real effect of the enzyme in protein digestibility.
In diets containing phytase, it was observed that $18 \%$ of crude protein resulted $(\mathrm{P}<0.05)$ in higher metabolizable energy in the diets containing 3,100 or 3,250 kcal of AME $/ \mathrm{kg}$ (Table 3). When diets with $16 \%$ of crude protein were used, the increase of AMEn was observed only if the energy values were raised during the formulation $(\mathrm{P}<0.05)$. These results contradict those obtained by Silva et al. (2008), who observed an increase of apparent metabolizable energy when decreased dietary crude protein. According to these authors, the reduction of dietary nitrogen decreases the excretion of this element by birds, improving the energy use when the nitrogen balance is corrected. It is important to consider that these authors worked with young animals (1-21 days of age), which have high rates of nitrogen retention. According to Fukuyama et al. (2008), the level of $500 \mathrm{PTU} / \mathrm{kg}$ of phytase is insufficient to increase the metabolizable energy of feed, but 750 to 1,000 PTU is sufficient.

No interaction $(\mathrm{P}>0.05)$ was observed between protein and energy when only phytase diets were considered with regard to the apparent metabolizable energy of diets. These suggest that the difference between the levels studied was not sufficient to affect these values when using broilers from 22 to 42 days of age. However, when converting metabolizable energy to natural matter, it was observed that the energy values tof the experimental diets were different from the calculated values. The birds fed $14 \%$ crude protein diets were, on average, $103 \mathrm{kcal}$ of AMEn/kg lower than expected. On the other hand, diets with $16 \%$ of crude protein were $57 \mathrm{kcal}$ of AMEn/kg above the calculated values. This result may be related to better balance of amino acids and protein in the diet, resulting in higher energy utilization by birds.

Phytase supplementation influenced $(\mathrm{P}<0.05)$ the urinary excretion of nitrogen, phosphorus, calcium, potassium and zinc, but did not affect $(\mathrm{P}>0.05)$ copper excretion (Table 4). At all levels of energy and protein studied, 500 PTU/kg of

Table 3 - Corrected apparent metabolizable energy (AMEn) of diets containing different levels of energy and crude protein supplemented with phytase for broilers

\begin{tabular}{lcccc}
\hline AMEn (kcal/kg) & \multicolumn{3}{c}{ Crude } & protein \\
\cline { 2 - 4 } & 14.0 & 16.0 & 18.0 & \\
\hline 2,950 & $3,329 *$ & 3,360 & $3,256^{*}$ & 3,315 \\
3,100 & 3,356 & 3,501 & $3,556^{*}$ & 3,471 \\
3,250 & 3,396 & $3,698^{*}$ & $3,579^{*}$ & 3,558 \\
Mean $^{\text {Control }^{1}}$ & 3,360 & 3,520 & 3,464 & \\
Coefficient of variation (\%) $^{2}$ & 3,434 & & & \\
\hline
\end{tabular}

* Significantly different from the control diet by Dunnet test $(\mathrm{P}<0.05)$.

${ }^{1}$ Control diet containing $19 \%$ of crude protein and 3,100 kcal $/ \mathrm{kg}$ of metabolizable energy. 
phytase were sufficient to reduce the levels of nitrogen, phosphorus and potassium in excreta. It is important to consider that this reduction is mainly caused by reduced intake of these elements resulting from the reduction of crude protein, phosphorus and soybean meal, which is rich in potassium. For calcium, better results were obtained with diets containing 14 and $16 \%$ of crude protein. For zinc, diets with 3,250 kcal of AMEn/kg promoted better results.

Table 4 - Excretion of nutrients by broilers from 39 to 42 days of age fed diets containing different levels of energy and protein supplemented with fitase ${ }^{1}$

\begin{tabular}{|c|c|c|c|c|}
\hline \multirow[t]{2}{*}{ AMEn (kcal/kg) } & \multicolumn{3}{|c|}{ Crude protein (\%) } & \multirow[t]{2}{*}{ Average } \\
\hline & 14.0 & 16.0 & 18.0 & \\
\hline \multicolumn{5}{|c|}{ Nitrogen excretion (mg/bird/day) } \\
\hline 2,950 & $1,236 * \mathrm{c}$ & $1,448 * b$ & $1,733 * a A$ & 1,472 \\
\hline 3,100 & $1,155 * \mathrm{~b}$ & $1,478 * \mathrm{a}$ & $1,616^{*}$ aA & 1,417 \\
\hline 3,250 & $1,180 * b$ & $1,433 * a$ & $1,350 * a B$ & 1,321 \\
\hline Mean & 1,190 & 1,453 & 1,566 & 1,403 \\
\hline Control $^{2}$ & 2,054 & & & \\
\hline \multicolumn{2}{|c|}{ Coefficient of variation (\%) } & 10.38 & & \\
\hline \multicolumn{5}{|c|}{ Phosphorus excretion (mg/bird/day) } \\
\hline 2,950 & $408 *$ & $402 *$ & $403 *$ & $404 \mathrm{~A}$ \\
\hline 3,100 & $379 *$ & $407^{*}$ & $401 *$ & $395 \mathrm{~A}$ \\
\hline 3,250 & $353 *$ & $367 *$ & $320 *$ & $347 \mathrm{~B}$ \\
\hline Mean & 380 & 392 & 375 & 382 \\
\hline Control & 499 & & & \\
\hline \multicolumn{2}{|c|}{ Coefficient of variation (\%) } & 7.73 & & \\
\hline \multicolumn{5}{|c|}{ Calcium excretion (mg/bird/day) } \\
\hline 2,950 & 483 & $427 * \mathrm{~A}$ & 496A & 468 \\
\hline 3,100 & $439 * a$ & $354 * b B$ & $488 \mathrm{aA}$ & 427 \\
\hline 3,250 & $407 * b$ & $469 *$ a A & $370 * \mathrm{bB}$ & 416 \\
\hline Mean & 443 & 417 & 452 & 437 \\
\hline Control & 572 & & & \\
\hline \multicolumn{2}{|c|}{ Coefficient of variation (\%) } & 12.95 & & \\
\hline \multicolumn{5}{|c|}{ Potassium excretion (mg/bird/day) } \\
\hline 2,950 & $691 *$ & $749 *$ & $844 *$ & $761 \mathrm{~A}$ \\
\hline 3,100 & $649 *$ & $739 *$ & $857 *$ & $748 \mathrm{~A}$ \\
\hline 3,250 & $589 *$ & $695 *$ & $683^{*}$ & $656 \mathrm{~B}$ \\
\hline Mean & $643 c$ & $728 b$ & 795a & 722 \\
\hline Control & 951 & & & \\
\hline \multicolumn{5}{|c|}{ Coefficient of variation (\%) } \\
\hline \multicolumn{5}{|c|}{ Copper excretion (mg/bird/day) } \\
\hline 2,950 & 0.594 & 0.663 & 0.608 & $0.621 \mathrm{~A}$ \\
\hline 3,100 & 0.587 & 0.686 & 0.581 & $0.618 \mathrm{~A}$ \\
\hline 3,250 & 0.516 & 0.646 & 0.510 & $0.557 \mathrm{~B}$ \\
\hline Mean & $0.566 b$ & $0.665 a$ & $0.566 \mathrm{~b}$ & 0.599 \\
\hline Control & 0.596 & & & \\
\hline Coefficient of va & ariation (\%) & 12.17 & & \\
\hline \multicolumn{5}{|c|}{ Zinc excretion (mg/bird/day) } \\
\hline 2,950 & 9.3 & 8.9 & $7.9^{*}$ & $8.7 \mathrm{~B}$ \\
\hline 3,100 & 9.1 & 9.7 & 9.3 & $9.4 \mathrm{~A}$ \\
\hline 3,250 & $7.9 *$ & $8.0 *$ & $7.7 *$ & $7.9 \mathrm{C}$ \\
\hline Mean & 8.8 & 8.9 & 8.3 & 8.7 \\
\hline Control & 9.7 & & & \\
\hline Coefficient of va & ariation $(\%)$ & 9.89 & & \\
\hline
\end{tabular}

* Mean differ from control diet by Dunnet test $(\mathrm{P}<0.05)$.

${ }^{1}$ Means followed by different lowercase letters within line and capital letters within column differ by SNK test $(\mathrm{P}<0.05)$.

${ }^{2}$ Control diet containing $19 \%$ of crude protein and 3,100 kcal $/ \mathrm{kg}$ of metabolizable energy.
Silva et al. (2008) observed reduction of nitrogen, zinc and also copper in excrements of the broilers from 1 to 21 days of age using phytase in diets with reduced crude protein containing synthetic amino acids. Laurentiz et al. (2009), working with normal levels of crude protein for growing broilers found no effect of phytase on the excretion of copper or zinc but significant reduction of phosphorus using 500 or $1,000 \mathrm{PTU} / \mathrm{kg}$. Assuena et al. (2009) also observed reduction of phosphorus excretion but not nitrogen when using phytase for broiler growth. According to Mroz et al. (1994), phytic acid may inactivate enzymes such as trypsin and pepsin, interfering with the nutrient digestibility, especially protein in this case. However, by comparing the results of this study to the literature, it is suggested that the higher activity of phytase on phosphorus release and the reduction of nitrogen in excreta were certainly due to decreased protein with the inclusion of crystalline amino acids. Fukayama et al. (2008) found that 1,000 PTU/ $\mathrm{kg}$ of phytase was not sufficient to alter the protein digestibility, but it was sufficient to alter the digestibility of calcium and phosphorus.

The improvement of phosphorus digestibility and its utilization by animals can explain the lesser amount of phosphorus in excrements of birds fed diets with lower phosphorus content and maintained their performance. This suggests that phytase really breaks the complex phytate-mineral, facilitating the absorption of phosphorus and decreasing its excretion. This also shows that it is possible to decrease the excretion of nutrients to the environment when using additives such as phytase. Furthermore, the reduction in percentage of available phosphorus in the diets increases the retention of minerals indispensable for maintaining the physiological functions of the birds (Ravindran et al., 2000).

Improvement in the mineral digestibility in the phytase diets was probably caused by the break-down into phytatemineral complex, facilitating the mineral absorption and, consequently, reducing their excretion (Sebastian et al., 1996). However, the relationship between the available elements is also an important factor to be taken into account, such as the relationship between amino acids. The best use of minerals by organism also occurs when there is an adequate balance among all elements in tissues.

Comparing only diets containing phytase, there was an interaction $(\mathrm{P}<0.05)$ between dietary energy and crude protein levels on nitrogen excretion. Dietary energy affect the excretion of this element only in $18 \%$ crude protein diets, but the same effect was not observed in diets with 14 or $16 \%$ of crude protein. In the first case, high energy is related to lower feed intake, which may have been responsible for the 
results in diets with $18 \%$ of crude protein. In the case of diets with 14 or $16 \%$ of crude protein, the level of nitrogen intake is more limited and it is close to the bird requirements.

Diets containing $14 \%$ of crude protein reduced nitrogen excretion in all dietary energy levels studied, because of the smaller amount of this element in the diet. Similar results were obtained by Faria Filho et al. (2005), who studied broilers in the initial phase receiving diets varying from 18.5 to $21.5 \%$ of crude protein. In the present work, the reduction from 18 to $16 \%$ of crude protein was not enough to change this value except in diets containing $2,950 \mathrm{kcal}$ AMEn/kg. By these results, it was observed a reduction of approximately $8.8 \%$ of nitrogen for each $1.0 \%$ of crude protein reduced when compared to the control diet.

Only the energy levels on the diet affected $(\mathrm{P}<0.05)$ the phosphorus excretion, probably by the reduction in consumption of this element. The reduction of crude protein in diets with phytase did not influence $(\mathrm{P}>0.05)$ the phosphorus excretion, which was similar to results obtained by Silva et al. (2008). According to these authors, only the reduction of phosphorus associated with dietary phytase may reduce the elimination of this element and maintain the performance of the broilers. In this work, the reduction of crude protein with the inclusion of crystalline amino acids did not affect the concentration of phosphorus in the excreta either.

Even when phytase diets were considered, those containing the energy level recommended for this phase $(3,100 \mathrm{kcal} A M E n / \mathrm{kg})$ in $16 \%$ of crude protein decreased the calcium excretion, but in diets with $18 \%$ crude protein, the energy level should increase to 3,250 kcal of AMEn/kg to maintain these results. This indicates that despite the higher utilization of dietary minerals by birds, other nutrients and energy levels should also be considered. In this case, enzymes can influence the good use of nutrients in the diets.

Regarding to the potassium and copper excretion by broilers receiving phytase diets, there was no interaction $(\mathrm{P}>0.05)$ between energy and crude protein level in the diet. With phytase, diets with 3,250 kcal of AMEn/kg and $14 \%$ of crude protein showed the best results. Although $18 \%$ of crude protein diets result in lesser copper excretion, these diets increased the potassium excretion because of the higher quantity of soybean meal in diets. As the zinc excretion, only the energy levels were affected $(\mathrm{P}<0.05)$. The $3,250 \mathrm{kcal}$ of AMEn/ $\mathrm{kg}$ resulted in the best results.

The addition of phytase in diets with reduced crude protein containing crystalline amino acids still has many limitations, especially when considering the relationship among amino acids, minerals and energy in the diets. The ratio of dietary nutrients with dietary energy is an important factor to be considered in order to reduce the production cost of feed, improving the producer profitability and decreasing the environment impact from polluting elements in broiler excrements.

\section{Conclusions}

Dietary energy should be raised to 3,250 kcal AMEn/kg and crude protein, calcium and phosphorus should be reduced to $18.0,0.70$ and $0.31 \%$, respectively in diets supplemented with phytase and crystalline amino acids, according to the ideal protein concept. This protocol improves performance of broilers at 22 to 42 days of age and reduces the excretion of pollutants in excrements.

\section{References}

ASSUENA, V.; JUNQUEIRA, O.M.; DUARTE, K.F. et al. Effect of dietary phytase suplementation on the performance, bone densitometry, and phosphorus and nitrogen excretion of broilers. Revista Brasileira de Ciência Avícola, v.11, n.1, p.25-30, 2009.

BARBOSA, L.C.G.S.; ARAÚJO, L.F; JUNQUEIRA, O.M. et al. Redução dos níveis protéicos da dieta para frangos de corte durante a fase de crescimento. Revista Brasileira de Ciência Avícola, v.7, p.111, 2005 (supl.).

BARBOSA, F.J.V.; LOPES, J.B.; FIGUEIRÊDO, A.V. et al. Níveis de energia metabolizável em rações para frangos de corte mantidos em ambiente de alta temperatura. Revista Brasileira de Zootecnia, v.37, n.5, p.849-855, 2008

CAMDEN, B.J.; MOREL, P.C.H.; THOMAS, D.V. et al. Effectiveness of exogenous microbial phytase in improving the bioavailabilities of phosphorus and other nutrients in maize -soya-bean meal diets for broilers. Animal Science, v.73, n.2, p.289-297, 2001.

FARIA FILHO, D.E.; ROSA, P.S.; VIEIRA, B.S. et al. Protein levels and environmental temperature effects on carcass characteristics, performance, and nitrogen excretion of broiler chickens from 7 to 21 days of age. Revista Brasileira de Ciência Avícola, v.7, n.4, p.247-253, 2005.

FERNANDES, E.A.; FONSECA, D.P.; COSTA, D.R. et al. Efeito da redução nos níveis de proteína bruta da dieta de frangos de corte. Revista Brasileira de Ciência Avícola, v.7, p.51, 2005 (supl.).

FERREIRA, D.F. Análises estatísticas por meio do SISVAR para Windows versão 4. 0. In: REUNIÃO ANUAL DA REGIÃO BRASILEIRA DA SOCIEDADE INTERNACIONAL DE BIOMETRIA, 45., 2000, São Carlos. Anais... São Carlos: UFSCar, 2000. p.255-258.

FUKAYAMA, E.H.; SAKOMURA, N.K.; DOURADO, L.R.B. Efeito da suplementação de fitase sobre o desempenho e a digestibilidade dos nutrientes em frangos de corte. Revista Brasileira de Zootecnia, v.37, n.4, p.629-635, 2008.

GATES, R.S. Poultry diet manipulation to reduce output of pollutants to environment. In: SIMPÓSIO SOBRE RESÍDUOS DA PRODUÇÃO AVÍCOLA, 2000, Concórdia. Anais... Concórdia: EMBRAPA, 2000. p.62-74.

GOMIDE, E.M.; RODRIGUES, P.B.; FREITAS, R.T.F. et al. Planos nutricionais com a utilização de aminoácidos e fitase para frangos 
de corte mantendo o conceito de proteína ideal nas dietas. Revista Brasileira de Zootecnia, v.36, n.6, p.1769-1774, 2007.

LAURENTIZ, A.C.; JUNQUEIRA, O.M.; FILARDI, R.S. Desempenho, composição da cama, das tíbias, do fígado e das excretas de frangos de corte alimentados com rações contendo fitase e baixos níveis de fósforo. Revista Brasileira de Zootecnia, v.38, n.10, p.1938-1947, 2009.

MATTERSON, L.D.; POTTER, L.M.; STUTZ, M.W. et al. The metabolizable energy of feed ingredients for chickens. Storss, Connecticut: The University of Connecticut, Agricultural Experiment Station, 1965. 11p. (Research Report, 7).

MROZ, Z.; JONGBLOED, A.W.; KEMME, P.A. Apparent digestibility and retention of nutrients bound to phytate complexes as influenced by microbial phytase and feeding regimen in pigs. Journal of Animal Science, v.72, n.1, p.126-132, 1994.

OLIVEIRA, R.F.M.; ZANUSSO, J.T.; DONZELE, J.L. et al. Níveis de energia metabolizável para frangos de corte de 1 a 21 dias de idade mantidos em ambiente de alta temperatura. Revista Brasileira de Zootecnia, v.29, n.3, p.810-816, 2000.

OLIVEIRA NETO, A.R.; OLIVEIRA, W.P. Aminoácidos para frangos de corte. Revista Brasileira de Zootecnia, v.38, p.205-208, 2009 (supl. especial).

RAVINDRAN, V.; CABAHUG, S.; RAVINDRAM, G. et al. Response of broilers to microbial phytase supplementation as influenced by dietary phytic acid and non-phytate phosphorus levels. II. Effects on nutrient digestibility and retention. British Poultry Science, v.41, n.2, p.193-200, 2000.

RIGUEIRA, L.C.M.; ROSTAGNO, H.S.; ALBINO, L.F.T. et al. Níveis de proteína e de aminoácidos nas dietas de frangos de corte machos e fêmeas no período de 21 a 35 dias de idade. Revista Brasileira de Ciência Avícola, v.7, p.137, 2005 (supl.).

RODRIGUES, P.B.; MARTINEZ, R.S.; FREITAS, R.T.F. et al. Influência do tempo de coleta e metodologias sobre a digestibilidade e o valor energético de rações para aves. Revista Brasileira de Zootecnia, v.34, p.882-889. 2005

ROSTAGNO, H.S.; ALBINO, L.F.T.; DONZELE, J.L. et al. Tabelas brasileiras para aves e suínos. Composição de alimentos e exigências nutricionais. Viçosa, MG: UFV, 2000. 141p.

ROSTAGNO, H.S.; VARGAS JUNIOR, J.G.; ALBINO, L.F.T. et al. Níveis de proteína e aminoácidos em rações de pinto de corte. Revista Brasileira de Ciência Avícola, v.4, p.49, 2002 (supl.). SEBASTIAN, S.; TOUCHBURN, S.P.; CHAVEZ, E.R. et al. The effects of supplemental microbial phytase on the performance and utilization of dietary calcium, phosphorus, copper, and zinc in broiler chickens fed corn-soybean diets. Poultry Science, v.75, n.6, p.729-736, 1996.

SILVA, J.H.V.; ALBINO, L.F.T.; NASCIMENTO, A.H. Níveis de energia e relações energia:proteína para frangos de corte de 22 a 42 dias de idade. Revista Brasileira de Zootecnia, v.30, n.6, p.1791-1800, 2001.

SILVA, D.J.; QUEIROZ, A.C. Análise de alimentos: métodos químicos e biológicos. 3.ed. Viçosa, MG: UFV. Imprensa Universitária, 2002. 235p.

SILVA, Y.L.; RODRIGUES, P.B.; FREITAS, R.T.F. Redução de proteína e fósforo em rações com fitase para frangos de corte no período de 1 a 21 dias de idade. Desempenho e teores de minerais na cama. Revista Brasileira de Zootecnia, v.35, n.3, p.840-848, 2006.

SILVA, Y.L.; RODRIGUES, P.B.; FREITAS, R.T. Níveis de proteína e fósforo em rações com fitase para frangos de corte, na fase de 14 a 21 dias de idade. 2. Valores energéticos e digestibilidade de nutrientes. Revista Brasileira de Zootecnia, v.37, n.3, p.469-477, 2008

VIEIRA, S.L.; OLMOS, A.R.; BERRES, J. et al. Respostas de frangos de corte fêmeas de duas linhagens a dietas com diferentes perfis protéicos ideais. Ciência Rural, v.37, n.6, p.1753-1759, 2007. 